\title{
Bacterial Flora of Milkfish, Chanos chanos, Eggs and Larvae
}

\author{
Roselyn D. Fernandez*, Eleanor A. Tendencia, \\ Eduardo M. Leaño and Marietta N. Duray \\ Southeast Asian Fisheries Development Center (SEAFDEC), Aquaculture \\ Department (AQD) 5021 Tigbauan, Iloilo Philippines
}

(Received December 27, 1995)

\begin{abstract}
Aerobic bacterial flora of eggs and larvae of milkfish, Chanos chanos, was investigated. Microflora in the incubating water of egg, rearing water of larvae, water source, and larval food was also analyzed.

Aerobic bacterial flora of milkfish eggs was largely influenced by the bacterial flora in the incubating water. Both in eggs and in the incubating water Pseudomonas species were the dominant bacteria. During milkfish larval rearing, intestinal aerobic bacterial flora was examined at days 1, 3, 7, 10, 15, 18, and 21 . Bacterial number in the larvae and rearing water significantly increased during the culture period up to day 18 but dropped significant at day 21. Pseudomonas species were detected from yolk-sac larvae (day 1) as the dominant bacteria, similarly to the normal flora in the rearing water. However, intestinal bacteria were predominated with Vibrio species when the yolk-sac was absorbed on day 3. Larval rearing water, water source, and larval food contained predominantly Pseudomonas species.
\end{abstract}

Key words : aerobic bacterial flora, milkfish, egg, larvae, Vibrio, Pseudomonas, Chanos chanos

Milkfish (Chanos chanos) is an important aquaculture commodity in most Southeast Asian countries. In the Philippines, success was achieved in the early 1980's on milkfish broodstock development, natural spawning, mass seed production and larval rearing techniques. However, survival rates from hatching up to larval rearing period is still low, 38\% (Kohno and Duray, 1989).

Speculations on the involvement of the microflora of egg surface on the hatching rates and mortalities in various species of fish eggs had led to numerous scientific investigations. Noteworthy, however, is that most of these studies were conducted on cold water fish species such as salmonids (Bell et al., 1971; Sauter et al., 1987; Cahill, 1990) and halibut (Bergh et al., 1992). Furthermore, in tropical conditions there is limited information on egg and larval microflora, except a few recent works (Ogbondeminu, 1994).

Mass mortalities due to bacterial diseases in seed production of marine finfish is an important problem during larval rearing (Muroga, 1992). To elucidate pathogenesis of these bacterial pathogens and assess

\footnotetext{
* Correspondence: Roselyn D. Fernandez, Fish Health Section, SEAFDC/AQD, 5021 Tigbauan, Iloilo, Philippines
}

the role of gastro intestinal microflora in several marine finfishes, intestinal microflora of larval and juvenile stages were investigated (Yoshimizu and Kimura, 1976; Muroga et al., 1987; Tanasomwang and Muroga, 1988). Results obtained varied each other showing that intestinal flora were influenced mainly by flora of food ingested and/or flora of the environment.

This paper aims to establish the aerobic bacterial flora of a tropical marine fish, milkflsh from eggs to larval rearing in hatchery.

\section{Materials and Methods}

\section{Milkfish eggs}

Milkfish eggs (average diameter: $1.1 \mathrm{~mm}$ ) used for this study were spawned from milkfish broodstock reared in cages at the Igang Marine Station (IMS) and in concrete tanks at Tigbauan Main Station (TMS), Southeast Asian Fisheries Development Center (SEAFDEC), Tigbauan, Iloilo, Philippines. Eggs spawned at IMS were immediately transported to TMS ( $2 \mathrm{~h}$ travel time) where measurement of bacterial counts in eggs and incubating water medium was immediately performed. A total of eight batches of milkfish eggs from IMS and two 


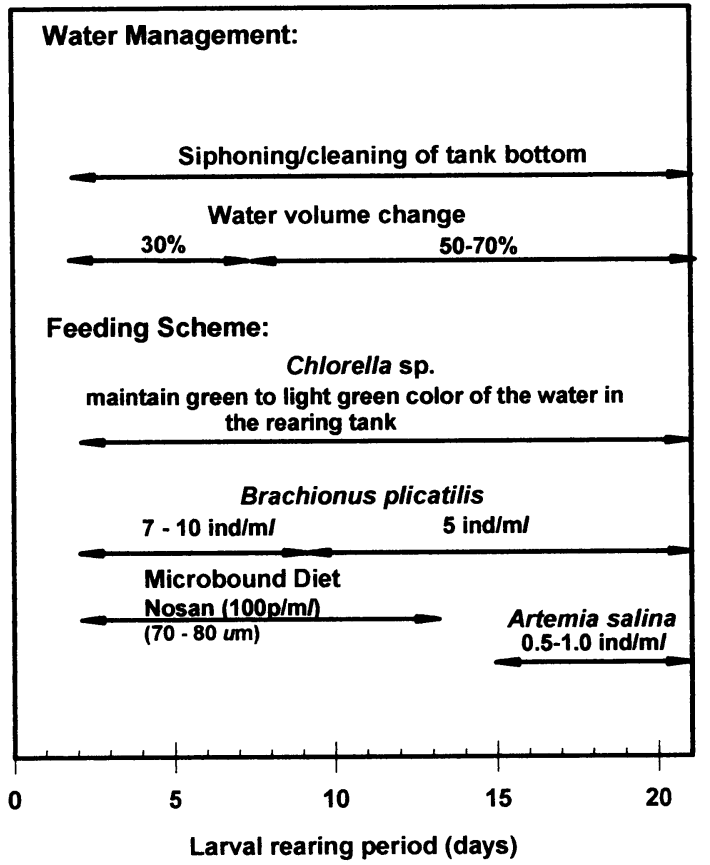

Fig. 1. Water management and modified feeding scheme for milkfish larval rearing (after Marte and Duray, 1991).

from TMS were determined.

\section{Milkfish larvae}

Eggs were pooled and hatched in a 5-ton tank at an initial density of 30 eggs per liter. Larvae were maintained in this tank until harvest at day 21. Larvae were fed Brachionus plicatilis from day 2 to 15, and thereafter fed Artemia nauplii. Management schemes for larval rearing were done following Marte and Duray (1991) (Fig. 1). Intestinal microflora of the larvae was determined at days $1,3,7,10$, $13,15,18$, and 21 of the rearing period. A total of 7 runs were done and analyzed for the aerobic bacterial flora.

\section{Bacterial isolation}

Several batches of 40-200 milkfish eggs spawned from a batch of captive spawners were collected for quantitative and qualitative determination of microflora. For this determination, several groups of 10 to 20 eggs each were placed in an improvised iodine solution-soaked mesh strainer, washed quickly (10$30 \mathrm{~s})$ under flowing tap water and rinsed in sterile neutral salt solution $(0.85 \% \mathrm{NaCl}, \mathrm{NSS})$. Washed eggs were homogenized in sterile homogenizing tubes using sterile NSS and diluted 10-fold. A $0.1 \mathrm{ml}$ of the two last dilutions from the homogenate was spread onto Zobell 2216e marine agar (ZM) (Aaronson, 1970) and Thiosulfate Citrate Bile Sucrose (TCBS) Agar (BBL). Bacterial counts were determined by spread plate method and expressed as colony forming units (CFU) per egg after incubation for $48 \mathrm{~h}$ at room temperature $\left(25^{\circ} \mathrm{C}-32^{\circ} \mathrm{C}\right)$. Samples from the incubating water were also inoculated onto the same medium. Each dominant colonies on ZM agar was determined and counted (\% incidence) and representative colonies of each dominant type of bacteria was isolated for characterization.

Quantitative and qualitative determination of microflora in larvae was done following almost the same method as in egg. However, to eliminate surface microflora and to include only intestinal bacteria, surface of larvae was disinfected with 50 $100 \mathrm{ppm}$ Argentyne (10\% iodine solution). Five groups of larvae (20 larvae per group, a total of 100 larvae per tank) was placed in the mesh strainer, soaked with the disinfectant for $1 \mathrm{~min}$, then washed with flowing tap water and finally rinsed with sterile NSS. Disinfected and thoroughly rinsed larval samples were homogenized in sterile homogenizing tubes with sterile NSS and was diluted serially 10 -fold. A $0.1 \mathrm{~m} l$ of diluted homogenate was spread onto $\mathrm{ZM}$ and TCBS agars. Inoculated plates were incubated for $48 \mathrm{~h}$ at room temperature $\left(25^{\circ} \mathrm{C}-32^{\circ} \mathrm{C}\right)$. After incubation, number of colonies on both media was counted and the average number of bacteria per larvae was calculated. The number of larvae in each group was reduced to 10 at days $13,15,18$ and 21 . Bacterial counts and flora from the water source, rearing tank of larvae, and diets were also obtained by the same method, except that these samples were not disinfected. Bacterial counts for the larvae were expressed as CFU per larvae while in the rearing water and natural food was expressed as CFU per $\mathrm{ml}$ and gram, respectively. Percentage incidence and isolation of predominant bacteria was done as before. Isolates were identified following Donovan and Furniss (1985) and Kreig and Holt (1984).

The relationship between bacterial counts in the larvae with larval rearing water, water source, and larval food were analyzed by correlation coefficients ' $r$ '. Data on bacterial counts in ZM and TCBS from larvae and from rearing water was analyzed using analysis of variance followed by Duncan's Multiple 
Range Test and Student's T-test.

\section{Results}

\section{Bacterial counts and flora of eggs}

Bacterial counts on ZM were significantly higher $(p>0.05)$ than on TCBS agar. On ZM, four to five groups of colonies were predominant and each representative colony of each group was identified. Both in the milkfish eggs and its incubating water medium, Pseudomonas sp. was the dominant bacteria regardless of month and source. Other bacterial species included Vibrio species, Plesiomonas, and Enterobacteriaceae and other unidentified bacteria (Table 1).

\section{Bacterial counts and flora of larvae}

Load of bacteria in milkfish larvae significantly $(p>0.01)$ increased with the days of culture (Fig. 2). Among other factors such as bacterial load in the water source, larval food, and rearing water (Table 2 ), only the load in the rearing water was correlated $(r=0.6961)$ with the counts in the larvae, showing a similar increasing trend of bacterial load. Qualitative bacterial examination showed that at days 1 and 2 of larval rearing, Pseudomonas dominated the intestinal flora of the milkfish larvae. However, from day 3 to day 21, larval intestine was completely dominated by Vibrio species. Although a few vibrios can be detected in the rearing water, our data indicated that Pseudomonas species. still dominates the larval rearing water, water source and larval food (Fig. 3).

A total of 238 bacterial isolates from the larvae were identified. Of these, 179 were presumptively identified as Vibrio species and 59 were nonvibrios.

\section{Discussion}

Bacterial flora of milkfish eggs was found to be a reflection of the normal flora in incubating water. This observation was similar to that obtained by Omnes et al. (1993) among turbot eggs. They con-

Table 1. Average bacterial count and flora of milkfish eggs and incubating water

\begin{tabular}{|c|c|c|c|c|c|c|c|c|}
\hline \multirow{2}{*}{ Source } & \multirow{2}{*}{ Date } & \multicolumn{2}{|c|}{ Bacterial count ( $\mathrm{CFU} / \mathrm{egg})$} & \multicolumn{5}{|c|}{ Flora $(\%)$} \\
\hline & & Zobells's $2216 \mathrm{E}$ & TCBS Agar & $P s^{3}$ & $V^{4}$ & $P l^{5}$ & $\mathrm{Ent}^{6}$ & Others \\
\hline \multicolumn{9}{|c|}{ A. Milkfish eggs: } \\
\hline IMS $^{1}$ & 31 May & $6.8 \times 10^{3}$ & $7.7 \times 10^{1}$ & 81.1 & 18.2 & 0.16 & 0.54 & - \\
\hline IMS & 01 June & $8.2 \times 10^{1}$ & 0.3 & 100.0 & - & - & - & - \\
\hline IMS & 06 June & $7.2 \times 10^{1}$ & 3.0 & 44.5 & 50.0 & - & - & 5.5 \\
\hline IMS & 08 June & $6.6 \times 10^{1}$ & $2.1 \times 10^{1}$ & 68.8 & 4.7 & - & 22.9 & 3.6 \\
\hline $\mathrm{TMS}^{2}$ & 09 June & $2.5 \times 10^{1}$ & $\mathrm{nd}^{*}$ & 100.0 & - & - & - & - \\
\hline TMS & 17 June & $3.9 \times 10^{3}$ & $2.9 \times 10^{3}$ & & & nd & & \\
\hline IMS & 04 July & $5.0 \times 10^{2}$ & 3.5 & 79.5 & 4.5 & 14.5 & - & 1.9 \\
\hline TMS & 05 July & 7.5 & $3.0 \times 10^{1}$ & 71.9 & 7.1 & 10.4 & 8.7 & 1.9 \\
\hline IMS & 14 July & $1.3 \times 10^{2}$ & 2.0 & 67.4 & 2.4 & 4.3 & 25.0 & 0.9 \\
\hline IMS & 19 July & 3.0 & 0.0 & 98.9 & 0.6 & 0.3 & - & 0.2 \\
\hline IMS & 20 July & 3.5 & 0.0 & 99.4 & - & - & - & 0.6 \\
\hline IMS & 12 Aug. & $3.1 \times 10^{2}$ & 9.5 & & & nd & & \\
\hline IMS & 18 Oct. & $7.4 \times 10^{1}$ & nd & & & nd & & \\
\hline \multicolumn{9}{|c|}{ B. Incubating medium: } \\
\hline IMS & 06 June & $3.5 \times 10^{5}$ & $1.5 \times 10^{4}$ & 57.7 & - & 40.0 & - & - \\
\hline IMS & 08 June & $2.0 \times 10^{4}$ & $1.9 \times 10^{2}$ & 98.6 & - & - & 0.1 & 1.3 \\
\hline TMS & 09 June & $3.5 \times 10^{5}$ & nd & 100 & - & - & - & - \\
\hline TMS & 17 June & $2.8 \times 10^{5}$ & $5.5 \times 10^{1}$ & & & nd & & \\
\hline IMS & 04 July & $3.7 \times 10^{4}$ & $7.3 \times 10^{3}$ & 81.2 & 15.4 & - & - & 3.4 \\
\hline TMS & 05 July & $4.5 \times 10^{5}$ & $1.7 \times 10^{3}$ & 33.5 & - & 66.4 & 0.1 & - \\
\hline IMS & 14 July & $2.2 \times 10^{5}$ & $1.0 \times 10^{3}$ & 86.3 & - & - & - & 13.7 \\
\hline IMS & 19 July & $3.5 \times 10^{4}$ & $5.6 \times 10^{3}$ & - & 68.4 & 31.6 & - & - \\
\hline IMS & 20 July & $3.5 \times 10^{5}$ & $3.3 \times 10^{4}$ & 56.5 & - & - & 43.5 & - \\
\hline
\end{tabular}

${ }^{1}$ Igang Marine Station, ${ }^{2}$ Tigbauan Main Station, ${ }^{3}$ Pseudomonas sp., ${ }^{4}$ Vibrio sp., ${ }^{5}$ Plesiomonas shigelloides, ${ }^{6}$ Enterobacteriaceae, ${ }^{*}$ not determined. 


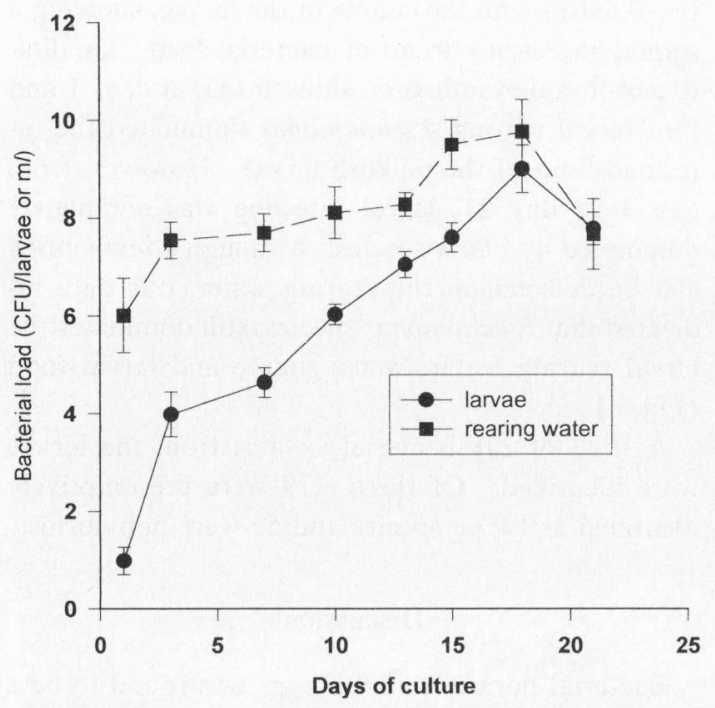

Fig. 2. Changes in bacterial load of milkfish larvae and rearing water. cluded that there was no apparent correlation between the number of bacteria and losses of eggs although hatching rates in turbot eggs were variable. Pseudomonads are common inhabitants in freshwater and marine environments and had been reported by several investigators as frequent microflora in embryonaated eggs (Bell et al., 1971; Yoshimizu et al., 1980; Cahill, 1990). Although its role is less understood, its presence is thought to be a result, rather than the cause of death, of nutrients leaching from the eggs. Death of eggs is probably the result of a complex relationship among the embryonated egg, its microflora and its ambient water (Bell et al., 1971).

Most reported studies on bacterial flora in fishes were documented in juveniles or assumed subadult and adult marine and freshwater finfishes with more or less developed intestines (Sakata et al., 1978; Nieto et al., 1984; Mcmillan and Santucci, 1990). As hypothesized by Shewan and Hobbs (1967) and

Table 2. Changes in the bacterial load of milkfish larvae, rearing water of larvae, water source, and larval food with the culture period (days)

\begin{tabular}{lcccccccc}
\hline \hline & \multicolumn{8}{c}{ Days culture } \\
\cline { 2 - 8 } & D1 & D3 & D7 & D10 & D13 & D15 & D18 & D21 \\
\hline Larvae (CFU/fish) & 2.70 & $5.3 \times 10^{1}$ & $1.0 \times 10^{2}$ & $3.6 \times 10^{2}$ & $1.2 \times 10^{3}$ & $2.0 \times 10^{3}$ & $8.2 \times 10^{3}$ & $2.4 \times 10^{3}$ \\
Rearing water (CFU/ml) & $4.1 \times 10^{2}$ & $1.9 \times 10^{3}$ & $2.2 \times 10^{3}$ & $3.3 \times 10^{3}$ & $3.2 \times 10^{3}$ & $1.3 \times 10^{4}$ & $1.7 \times 10^{4}$ & $2.1 \times 10^{3}$ \\
Water source (CFU/ml) & $1.2 \times 10^{2}$ & $1.0 \times 10^{3}$ & $3.9 \times 10^{4}$ & $6.7 \times 10^{3}$ & $2.0 \times 10^{3}$ & $1.1 \times 10^{3}$ & $1.2 \times 10^{3}$ & $3.4 \times 10^{2}$ \\
Larval food (CFU/ml or g) & - & $4.1 \times 10^{7}$ & $1.2 \times 10^{7}$ & $8.7 \times 10^{7}$ & $7.3 \times 10^{6}$ & $4.6 \times 10^{7}$ & $7.1 \times 10^{7}$ & $3.9 \times 10^{7}$ \\
\hline
\end{tabular}

\footnotetext{
- : no feeding.
}

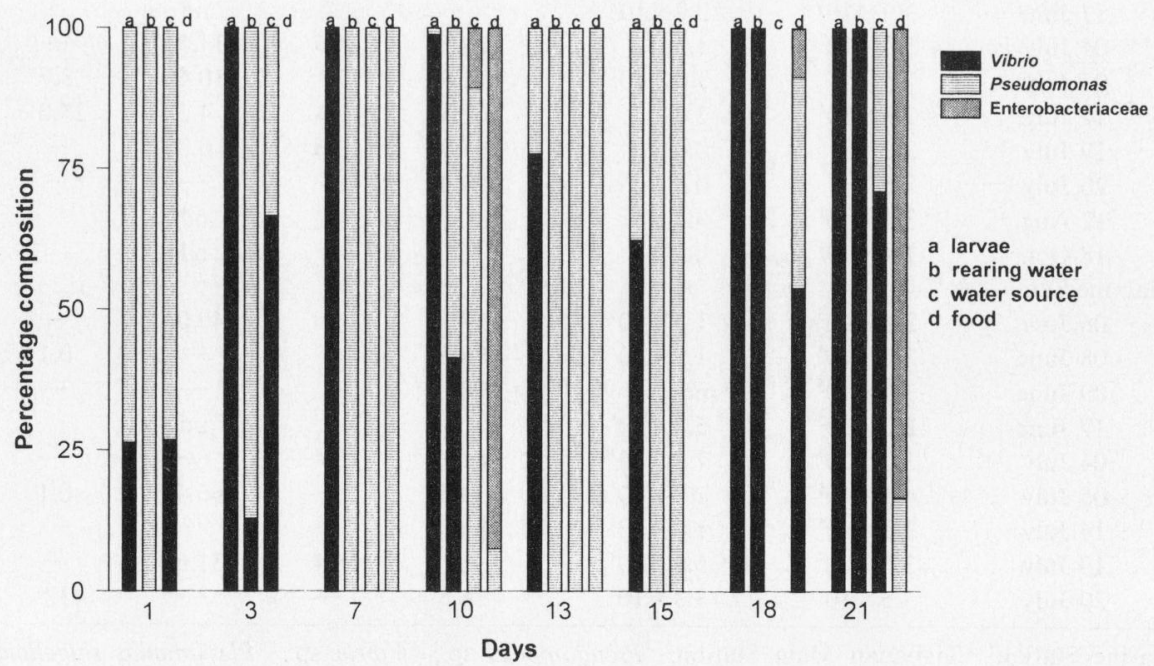

Fig. 3. Percentage composition of bacteria in milkfish larvae, rearing water, water source, and larval food. 
from the results in several studies, environmental microflora markedly influence surface and sometimes intestinal microflora (Nieto et al., 1984; Campbell and Buswell, 1983; Tanasomwang and Muroga, 1988; Cahill, 1990). However, this trend of relationship was hardly achieved in this study as in the results obtained by Yoshimizu and Kimura (1976) when genus Vibrio formed as the dominant species in the intestines of salmonids cultured in seawater. The present result suggests the selective propagation of Vibrio species in the intestines of milkfish larvae.

In tropical finfishes, there is limited information as to which types of bacteria are colonized in various stages of fish from developing fish eggs to larval stage. Intestinal bacteria in milkfish larvae were detected from the yolksac stage or even before exogenous feeding starts. Ingestion of bacteria by drinking and swallowing of mucus with bacteria was observed in 4 day-old yolksac cod (Gadus morhus) (Olafsen and Hansen, 1992). The same mechanism is possible in 1-2 day-old yolk-sac milkfish larvae which will ingest bacteria, largely dominated by Pseudomonas species from the environment. Intestinal bacteria were predominated by Vibrio when the yolksac was absorbed, that is on day 3 and until day 21. Reasons for the increased bacterial load in the larvae is not known but it is highly probable that there is enhanced bacterial attachment in the larval gut as a result of the histological and functional development of the larvae (Ringo et al., 1995).

The selective establishment of commensal intestinal microflora was hypothesized to involve certain mechanisms of uptake of intact bacterial antigens through the selective absorptive cells of developing foregut of early yolk-sac stage. Also evidence shows that this mechanism takes place in specialized cells of developing gut of marine fish larvae. Exposure of the larvae to bacterial antigens is necessary to develop tolerance. For bacteria to become established in larval intestines, tolerance to their exposed antigens must be acquired (Olafsen and Hansen, 1992). It is therefore tempting to speculate that this mechanism occurs and probably explains the selective establishment of vibrios in milkfish intestines.

A study was conducted by Ferraris et al. (1987) on the development of the digestive tract of milkfish. Predominance of Vibrio species on day 3 coincided with the developments of the digestive tract, ability to produce enzymes, and eye pigmentation and onset of feeding. This seems to indicate that a possible relationship exist between the presence of intestinal gut flora and enzyme production. Bacteria engulfed at larval stages may furnish essential nutrients, enzymes, or induce enzyme release before first feeding (Olafsen and Hansen, 1992). A number of evidences have also indicated the involvement of bacteria as important sources of enzymes for digestion (Hamid et al., 1979; Mowlah et al., 1979; Henebry et al., 1988; Shiranee et al., 1993).

The role of vibrios in milkfish larval intestines needs to be defined in future studies as it may suggest not only nutritional importance but may also have implication for an early immune development in one of the known hardy fish as milkfish.

\section{References}

Aaronson, S. (ed.) (1970): Experimental microbial ecology. Academic Press, New York, 236 p.

Bell, G. R., G. E. Hoskins and W. Hodgkiss (1971): Aspects of characterization, identification, and ecology of the bacterial flora associated with the surface of stream-incubating Pacific salmon (Oncorhynchus) eggs. J. Fish. Res. Board Can., 28, 1511-1525.

Bergh, O., G. H. Hansen and R. E. Taxt (1992): Experimental infection of eggs and yolk sac larvae of halibut, Hippoglossus hippoglossus L. J. Fish Dis., 15, 379-391.

Cahill, M. M. (1990): Bacterial flora of fishes: a review. Microbial Ecol., 19, 21-41.

Campbell, A. C. and J. A. Buswell (1983): The intestinal microflora of farmed Dover sole (Solea solea) at different stages of fish development. J. Appl. Bacteriol., 55, 215223.

Donovan, T. J. and A. L. Furniss (1985): Vibrios, Aeromonas, Plesiomonas, and Photobacterium. In: "Microbiological methods" (ed. by C. H. Collins and P. M. Lyne). England: Butterworth \& Co., Ltd., London, pp. 271-279.

Ferraris, R. P., J. D. Tan and M. C. de la Cruz (1987): Development of the digestive tract of milkfish, Chanos chanos (Forsskal): histology and histochemistry. Aquaculture, 61, 241-257.

Hamid, A., T. Sakata and D. Kakimoto (1979): Microflora in the alimentary tract of gray mullet-IV. Estimation of enzymatic activities of the intestinal bacteria. Bull. Jpn. Soc. Sci. Fish, 45, 99-106.

Henebry, M. S., R. W. Gorden and D. H. Buck (1988): Bacterial populations in the gut of silver carp (Hypophthalmichthys molitrix). Prog. Fish Cult., 50, 86-92.

Kohno, H. and M. Duray (1989): Schema of future milkfish studies with emphasis on qualitative characteristics of larvae. SEAFDEC Asian Aquacult., 11, 5-8.

Kreig, N. R. and J. G. Holt (eds) (1984): Bergey's Manual 
of Systematic Bacteriology, Vol. 1. Williams \& Wilkins, Baltimore, MD, 964 p.

Macmillan, J. R. and T. Santucci (1990): Seasonal trends in intestinal bacterial flora of farm-raised channel catfish. J. Aquat. Anim. Health, 2, 217-222.

Marte, C. L. and M. N. Duray (1991): Microbound larval feed as supplement to live food for milkfish (Chanos chanos) larvae. In: "Larvae '91-Fish and crustaceans larviculture symposium" (ed. by P. Lavens, P. Sorgeloos, P. Jaspes and F. Ollevier), European Aquaculture Society, Special Publ. No. 15, pp. 175-177.

Mowlah, A. H., T. Sakata and D. Kakimoto (1979): Microflora in the alimentary tract of gray mullet- $\mathrm{V}$. Studies on the chitinolytic enzymes of Enterobacter and Vibrio. Bull. Jpn. Soc. Sci. Fish., 45, 1313-1317.

Muroga, K. (1992): Bacterial and viral diseases of marine fish during seed production. NOAA Technical Report NMFS, 111, 57-61.

Muroga, K., M. Higashi and H. Keitoku (1987): The isolation of intestinal microflora of farmed red seabream (Pagrus major) and black seabream (Acanthopagrus schegeli) at larval and juvenile stages. Aquaculture, 65, 79-88.

Nieto, T. P., A. E. Toranzo and J. L. Barja (1984): Comparison between the bacterial flora associated with fingerling rainbow trout cultured in two different hatcheries in the North-west of Spain. Aquaculture, 42, 193206.

Ogbondeminu, F. S. (1994): Commensal bacterial microflora associated with incubating eggs of Clarias anguillaris in a tropical hatchery. J. Aquacult. Trop., 9, 151154.

Olafsen, J. A. and G. D. Hansen (1992): Intact antigen uptake in intestinal epithelial cells of marine fish larvae. J. Fish Biol., 40, 141-156.

Omnes, M. H., Y. Temey, J. Y. Daniel and J. L. Nicolas
(1993): Bacterial environment of gametes and embryos of turbot (Scophthalmus maximus). In: "From discovery to commercializaation" (ed. by M. Carrillo, L. Dahle, J. Morales, P. Sorgeloos, N. Svennevig and J. Wyban). European Aquaculture Society Special Publication No. 19. (Abstract only). p. 423.

Ringo, E., E. Strom and J.-A. Tabachek (1995): Intestinal microflora of salmonids: a review. Aquacult. Res., 26, 773-789.

Sakata, T., M. Nakaji and D. Kakimoto (1978): Microflora in the digestive tract of marine fish-I. General characterization of the isolates from yellow tail. Mem. Fac. Fish., Kagoshima Univ., 27, 65-71.

Sauter, R. W., C. Williams, E. A. Meyer, B. Celnik, J. L. Banks and D. A. Leith (1987): A study of bacteria present within unfertilized salmon eggs at the time of spawning and their possible relation to early lifestage disease. J. Fish Dis., 10, 193-203.

Shewan, J. M. and G. Hobbs (1967): The bacteriology of fish spoilage and preservation. In: "Progress in industrial microbiology" (ed. by D. J. D. Hockenhull), London: Iliffe Books Ltd., pp. 169-180.

Shiranee, P., P. Natarajan and R. Dhevendran (1993): The role of gut and sediment bacterial flora in the nutrition of cultured pearl spot (Etroplus suratensis, Bloch). Israeli J. Aquacult.-Bamidgeh, 45, 45-58.

Tanasomwang, V. and K. Muroga (1988): Intestinal microflora of larval and juveniles stages in Japanese flounder (Paralichthys olivaceus). Fish Pathol., 23, 7783.

Yoshimizu, M. and T. Kimura (1976): Studies on the intestinal microflora of salmonids. Fish Pathol., 10, 243259.

Yoshimizu, M., T. Kimura and M. Sakai (1980): Microflora of the embryo and fry of salmonids. Bull. Jpn. Soc. Sci. Fish., 46, 967-975. 